\title{
Sistem Pendukung Keputusan Untuk Menentukan Potensi Kecamatan Gawat Tuberculosis Pada Wilayah Kerja TB-HIV Care Aisyiyah Deli Serdang Menggunakan Metode Weighted Sum Model (WSM)
}

\author{
Prio Agung Wicaksono A. , Faisal Taufik*, Ismawardi Santoso * \\ Program Studi Sistem Informasi, STMIK Triguna Dharma
}

\begin{abstract}
Abstrak
Tuberculosis adalah penyakit menular yang sangat berbahaya, karena penularannya melewati udara. Penularan penyakit tuberculosis disebabkan oleh bakteri yang bernama Mycobacterium Tuberculosis yang terbang ketika penderita penyakit Tuberculosis batuk, bersin, atau berbicara dengan memercikkan ludah, bakteri TB akan ikut melalui ludah tersebut untuk terbang keudara. Selanjutnya, bakteri akan masuk ketubuh orang lain melalui udara yang dihirup. Oleh karena itu penularan penyakit TBC jarang bisa di pantau dan para penderita tidak mengetahui bahwa mereka sedang menderita penyakit TBC. Berdasarkan permasalahan tersebut, maka dibutuhkan sebuah sistem pendukung keputusan yang berguna untuk menentukan potensi kecamatan gawat penyakit TBC, agar penyebaran penyakit tersebut mudah di tanggulangi.

Dari uraian diatas perlu dibuat suatu sistem yang dapat membantu mengatasi permasalah tersebut yaitu dengan membangun sebuah sistem pendukung keputusan untuk menentukan potensi kecamatan gawat tuberculosis pada wilayah kerja TB-HIV Care Aisyiyah dengan menggunakan metode weighted sum model(wsm).

Hasil dari penelitian adalah, Pertama dapat memperoleh Kecamatan yang sesuai dengan kriteria itu sendiri dan akan menghasilkan sumber informasi yang berguna bagi TB-HIV Care, Kedua sistem ini dapat mempermudah untuk mengetahui proses pengolahan data kecamatan melalui sistem terkomputerisasi dan yang Ketiga sistem ini dapat membantu dalam menentukankecamatan yang berpotensi gawat tuberculosis, sehingga dapat diberikan penanganan lebih kepada para penderita.
\end{abstract}

Kata kunci : Sistem Pendukun Keputusan Metode WSM Tuberculosis TB HIV Care Aisyiyah

\begin{abstract}
Tuberculosis is a very dangerous infectious disease, because it is transmitted through the air. Transmission of tuberculosis is caused by a bacterium called Mycobacterium Tuberculosis which flies away when a person with Tuberculosis coughs, sneezes, or talks by splashing saliva, the TB bacteria will pass through the saliva to fly into the air. Furthermore, the bacteria will enter other people's bodies through the inhaled air. Therefore the transmission of TB disease can rarely be monitored and sufferers do not know that they are suffering from TB disease. Based on these problems, a decision support system is needed which is useful for determining the potential for distress TB disease districts, so that the spread of the disease can be easily controlled.

From the description above, it is necessary to make a system that can help overcome these problems, namely by building a decision support system to determine the potential for tuberculosis distress in the TB-HIV Care Aisyiyah working area using the weighted sum model (wsm) method.

The results of the research are, First, it can get a Subdistrict that fits the criteria itself and will produce a useful source of information for TB-HIV Care. determine the districts that are potentially serious for tuberculosis, so that more treatment can be given to sufferers.
\end{abstract}

Keywords: Decision Support System WSM Tuberculosis HIV Care Aisyiyah Method 


\section{PENDAHULUAN}

Tuberculosis adalah penyakit menular yang sangat berbahaya, karena penularannya melewati udara. Penularan penyakit tuberculosis disebabkan oleh bakteri yang bernama Mycobacterium Tuberculosis yang terbang ketika penderita penyakit Tuberculosis batuk, bersin, atau berbicara dengan memercikkan ludah, bakteri TB akan ikut melalui ludah tersebut untuk terbang keudara. Selanjutnya, bakteri akan masuk ketubuh orang lain melalui udara yang dihirup. Oleh karena itu penularan penyakit TBC jarang bisa di pantau dan para penderita tidak mengetahui bahwa mereka sedang menderita penyakit TBC. Untuk mengatasi permasalahan tersebut, maka dibutuhkan sebuah sistem pendukung keputusan untuk menentukan kecamatan yang berpotensi untuk gawat penyakit TBC agar bisa mudah di tanggulangi penyebaran penyakit tersebut.

TB-HIV Care Aisyiyah merupakan program penaggulangan penyakit Tuberculosis (TBC) berbasis masyarakat yang berupaya berperan serta dalam pembangunan kesehatan di Indonesia dan percapaian target Millenium Development Goal's nomor 6 yakni penurunan angka penyebaran penyakit menular. Pada saat ini TB-HIV Care Aisyiyah Deli Serdang kesulitan untuk menentukan penyebaran TBC dikarenakan penularan penyakit tersebut hanya melalui udara yang kasat mata. Para penderita TBC juga terkadang tidak menyadari bahwa mereka sedang terjangkit TBC. Maka dari itu dengan data pasien yang terdaftar pada TB-HIV Care Aisyiyah Deli Serdang dapat membantu menanggulangi penyebaran TBC yang ada selama ini.

Sistem pendukung keputusan adalah sistem berbasis computer interaktif, yang membantu para pengambil keputusan untuk menggunakan data dan berbagai model untuk memecahkan masalah-masalah yang tidak terstruktur. Berdasarkan permasalahan yang muncul maka diperlukan sistem pendukung keputusan yang menggunakan metode yang tepat yang dapat dijadikan pertimbangan untuk pengambil keputusan, salah satunya yaitu metode WSM (Weighted sum model), metode ini merupakan salah satu metode yang bisa membantu pengambilan. keputusan terhadap beberapa alternatif keputusan yang harus diambil dengan beberapa pertimbangan.

\section{METODE PENELITIAN}

Sebuah kerangka kerja penelitian dibuat untuk dijadikan sebagai pedoman dalam melaksanakan penelitian dan disusun ke dalam bentuk kerangka kerja (framework), dimana pada kerangka kerja yang dibuat dapat dilihat kegiatan-kegiatan dalam melakukan penelitian ini.

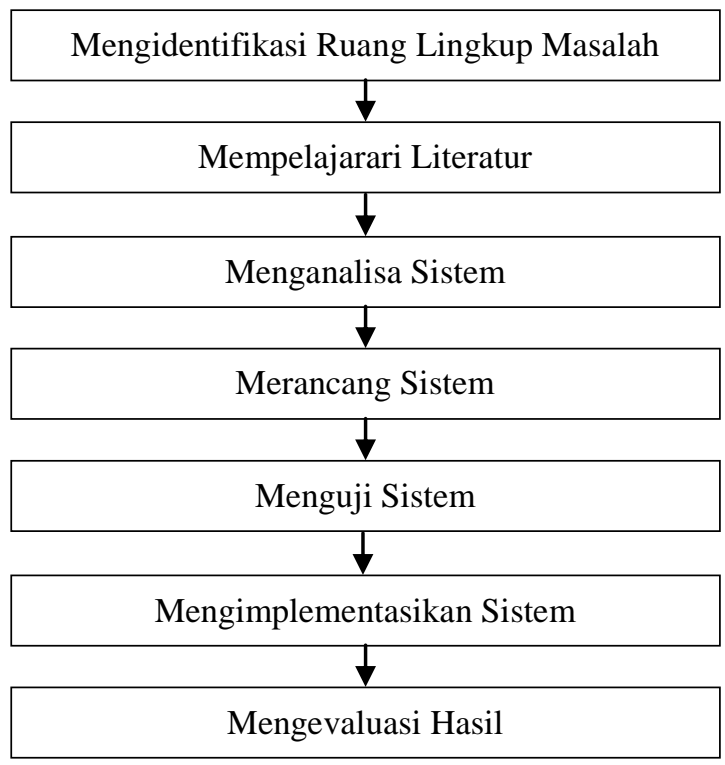

Gambar 1. Kerangka Kerja Penelitian 


\section{ANALISA DAN HASIL}

Permasalahan yang dihadapi adalah bagaimana cara menentukan kecamatan yang berpotensi gawat TBC agar dapat menurunkan angka kasus TBC di Deli Serdang. Dari permasalahan tersebut maka dilakukan cara membandingkan jumlah kasus dengan jumlah penduduk dalam suatu kecamatan agar dapat diketahui fokus penanganan penyakit TBC tersebut. Untuk menentukan kecamatan yang berpotensi TBC, maka dapat dicari dari perbandingan jumlah suspek dengan jumlah penduduk, kondisi kepadatan penduduk, indikator terduga, dan tingkat polusi udara pada kecamatan tersebut. Pemrosesan untuk menentukan kecamatan yang berpotensi TBC dengan menggunakan metode Weighted Sum Model (WSM) dari data awal sampai terbentuknya laporan.

Terdapat beberapa krtiteria yang telah ditentukan oleh TB HIV Care Aisyiyah Deli Serdang untuk menentukan kecamatan gawat TBC, yaitu:

1. Persentase jumlah suspek TBC dibandingkan jumlah penduduk.

2. Kondisi kepadatan penduduk

3. Indikator terduga

4. Tingkat polusi udara

5. Mengidentifikasi Kriteria Dan Alternatif

6. Sebelum menghitung nilai WSM-score terlebih dahulu mengidentifikasi kriteria yang dibutuhkan dalam menyeleksi kecamatan yang berpotensi gawat TBC pada wilayah kerja TB-HIV Care Aisyiyah Deli Serdang. Adapun kriteria dan nilai bobot kriteria dalam kecamatan yang berpotensi gawat TBC pada wilayah kerja TB-HIV Care Aisyiyah Deli Serdang dapat dilihat pada tabel dibawah ini :

7. Tabel 3.1 Kriteria Kecamatan Yang Berpotensi Gawat Tuberculosis

\begin{tabular}{|c|l|c|}
\hline Kode & \multicolumn{1}{|c|}{ Nama Kriteria } & Nilai Bobot $\mathbf{( W j )}$ \\
\hline C1 & Persentase Suspek & 0.4 \\
\hline C2 & Kepadatan Penduduk & 0.2 \\
\hline C3 & Indikator Terduga & 0.25 \\
\hline C4 & Polusi Udara & 0.15 \\
\hline
\end{tabular}

8. Dan berdasarkan data kecamatan yang ditangani oleh TB HIV Care Aisyiyah Deli Serdang yang disebut alternatif, berikut ini adalah tabel nilai alternatifnya:

Tabel 3.2 Nilai Dari Setiap Alternatif

\begin{tabular}{|c|l|c|c|c|l|}
\hline \multirow{2}{*}{ No } & \multirow{2}{*}{ Alternatif } & \multicolumn{4}{|c|}{ Nama Kriteria } \\
\cline { 3 - 6 } & & C1 & C2 & C3 & \multicolumn{1}{c|}{ C4 } \\
\hline 1 & Percut Sei Tuan & $0,0004 \%$ & Kumuh & Investigasi Kontak & Buruk \\
\hline 2 & Batang Kuis & $0,0014 \%$ & Layak & Rujukan & Buruk \\
\hline 3 & Tanjung Morawa & $0,0006 \%$ & Layak & Investigasi Kontak & Buruk \\
\hline 4 & Lubuk Pakam & $0,0012 \%$ & Layak & Rujukan & Baik \\
\hline 5 & Pagar Merbau & $0,0011 \%$ & Layak & Rujukan & Sangat Baik \\
\hline 6 & Galang & $0,0006 \%$ & Sangat Layak & Investigasi Kontak & Baik \\
\hline 7 & Bangun Purba & $0,0009 \%$ & Sangat Layak & Rujukan & Sangat Baik \\
\hline 8 & Deli Tua & $0,0009 \%$ & Layak & Rujukan & Baik \\
\hline
\end{tabular}

Tabel 3.3 Ketentun Untuk Kriteria C1

\begin{tabular}{|c|l|c|}
\hline Kriteria & \multicolumn{1}{|c|}{ Nilai } & Bobot \\
\hline \multirow{4}{*}{ Tes Psikologi } & Sangat Baik & 1 \\
\cline { 2 - 3 } & Baik & 0,75 \\
\cline { 2 - 3 } & Cukup Baik & 0,5 \\
\cline { 2 - 3 } & Kurang Baik & 0,25 \\
\hline
\end{tabular}

Tabel 3.4 Ketentuan Untuk Kriteria C2

\begin{tabular}{|c|l|c|}
\hline Kriteria & \multicolumn{1}{|c|}{ Nilai } & Bobot \\
\hline \multirow{4}{*}{ Tes Kesehatan } & Sangat Sehat & 1 \\
\cline { 2 - 3 } & Sehat & 0,75 \\
\cline { 2 - 3 } & Cukup Sehat & 0,5 \\
\cline { 2 - 3 } & Kurang Sehat & 0,25 \\
\hline
\end{tabular}


Tabel 3.5 Ketentuan Untuk Kriteria C3

\begin{tabular}{|c|l|c|}
\hline Kriteria & \multicolumn{1}{|c|}{ Nilai } & Bobot \\
\hline \multirow{4}{*}{ Tes Wawancara } & Sangat Baik & 1 \\
\cline { 2 - 3 } & Baik & 0,75 \\
\cline { 2 - 3 } & Cukup Baik & 0,5 \\
\cline { 2 - 3 } & Kurang Baik & 0,25 \\
\hline
\end{tabular}

Tabel 3.6 Ketentuan Untuk Kriteria C4

\begin{tabular}{|c|l|c|}
\hline Kriteria & \multicolumn{1}{|c|}{ Nilai } & Bobot \\
\hline \multirow{4}{*}{ Tes Jasmani } & Baik Sekali & 1 \\
\cline { 2 - 3 } & Baik & 0,75 \\
\cline { 2 - 3 } & Cukup Baik & 0,5 \\
\cline { 2 - 3 } & Kurang Baik & 0,25 \\
\hline
\end{tabular}

Tabel 3.7 Hasil Normalisasi

\begin{tabular}{|c|l|c|c|c|c|}
\hline \multirow{2}{*}{ No } & \multirow{2}{*}{ Alternatif } & \multicolumn{4}{|c|}{ Nama Kriteria } \\
\cline { 3 - 6 } & & C1 & C2 & C3 & C4 \\
\hline 1 & Percut Sei Tuan & 0.5 & 1 & 0.75 & 1 \\
\hline 2 & Batang Kuis & 1 & 0.75 & 1 & 1 \\
\hline 3 & Tanjung Morawa & 0.75 & 0.75 & 0.75 & 1 \\
\hline 4 & Lubuk Pakam & 1 & 0.75 & 1 & 0.75 \\
\hline 5 & Pagar Merbau & 1 & 0.75 & 1 & 0.5 \\
\hline 6 & Galang & 0.75 & 0.5 & 0.75 & 0.5 \\
\hline 7 & Bangun Purba & 1 & 0.5 & 1 & 0.5 \\
\hline 8 & Deli Tua & 1 & 0.75 & 1 & 0.75 \\
\hline
\end{tabular}

\subsection{Menghitung Nilai WSM-Score.}

Untuk melakukan perhitungan dengan menggunakan metode weighted sum model (WSM) maka penyelesaian dilakukan dengan rumus dibawah ini:

$$
A_{i}^{W S M-\text { score }}=\sum_{j=1}^{n} w_{j} x_{i j}
$$

Dimana :

$\mathrm{n} \quad=$ jumlah kriteria

$\mathrm{W}_{\mathrm{j}} \quad$ = bobot dari setiap kriteria

$\mathrm{X}_{\mathrm{ij}}=$ nilai matriks

Nilai WSM-Score Percut Sei Tuan (Alternatif 1)

$\mathrm{WSM}_{\text {Score }}=(0.4 * 0.75)+(0.2 * 1)+(0.25 * 0.5)+(0.15 * 1)$

$\mathrm{WSM}_{\text {Score }}=0.775$

Nilai WSM-Score Batang Kuis (Alternatif 2)

$\mathrm{WSM}_{\text {Score }}=(0.4 * 1)+(0.2 * 0.75)+(0.25 * 1)+(0.15 * 1)$

$\mathrm{WSM}_{\text {Score }}=0.95$

Nilai WSM-Score Tanjung Morawa (Alternatif 3)

$\mathrm{WSM}_{\text {Score }}=(0.4 * 0.75)+(0.2 * 0.75)+(0.25 * 0.75)+(0.15 * 1)$

$\mathrm{WSM}_{\text {Score }}=0.7875$

Nilai WSM-Score Lubuk Pakam (Alternatif 4)

$\mathrm{WSM}_{\text {Score }}=(0.4 * 1)+(0.2 * 0.75)+(0.25 * 1)+(0.15 * 0.75)$

$\mathrm{WSM}_{\text {Score }}=0.9125$ 
Nilai WSM-Score Pagar Merbau (Alternatif 5)

$\mathrm{WSM}_{\text {Score }}=(0.4 * 1)+(0.2 * 0.75)+(0.25 * 1)+(0.15 * 0.5)$

$\mathrm{WSM}_{\text {Score }}=0.875$

Nilai WSM-Score Galang (Alternatif 6)

$\mathrm{WSM}_{\text {Score }}=(0.4 * 0.75)+(0.2 * 0.5)+(0.25 * 0.75)+(0.15 * 0.5)$

$\mathrm{WSM}_{\text {Score }}=0.6625$

Nilai WSM-Score Bangun Purba (Alternatif 7)

$\mathrm{WSM}_{\text {Score }}=(0.4 * 1)+(0.2 * 0.5)+(0.25 * 1)+(0.15 * 0.5)$

$\mathrm{WSM}_{\text {Score }}=0.825$

Nilai WSM-Score Deli Tua (Alternatif 8)

$\mathrm{WSM}_{\text {Score }}=(0.4 * 1)+(0.2 * 0.75)+(0.25 * 1)+(0.15 * 0.75)$

$\mathrm{WSM}_{\text {Score }}=0.9125$

Tabel 3.8 Perangkingan Metode Weighted Sum Model

\begin{tabular}{|c|l|c|c|}
\hline No & \multicolumn{1}{|c|}{ Alternatif } & $\begin{array}{c}\text { Nilai Bobot } \\
\text { Prefersensi (Vi) }\end{array}$ & Keterangan \\
\hline 1 & Percut Sei Tuan & 0.775 & Rangking 7 \\
\hline 2 & Batang Kuis & 0.95 & Rangking 1 \\
\hline 3 & Tanjung Morawa & 0.7875 & Rangking 6 \\
\hline 4 & Lubuk Pakam & 0.9125 & Rangking 2 \\
\hline 5 & Pagar Merbau & 0.875 & Rangking 4 \\
\hline 6 & Galang & 0.6625 & Rangking 8 \\
\hline 7 & Bangun Purba & 0.825 & Rangking 3 \\
\hline 8 & Deli Tua & 0.9125 & \\
\hline
\end{tabular}

Berdasarkan tabel perangkingan diatas, maka dapat di ketahui alternatif 2 Kecamatan Batang Kuis mendapat nilai tertinggi yaitu 0.95 dan akan diprioritaskan dalam penanganan kasus TBC pada TB HIV Care Aisyiyah Deli Serdang.

\subsection{Implementasi Program}

Program yang dibangun berbasis desktop yang dapat digunakan untuk memproses normalisasi data alternatif menjadi sesuai dengan range yang telah ditentukan, lalu menghitung nilai akhir menggunakan metode WSM.

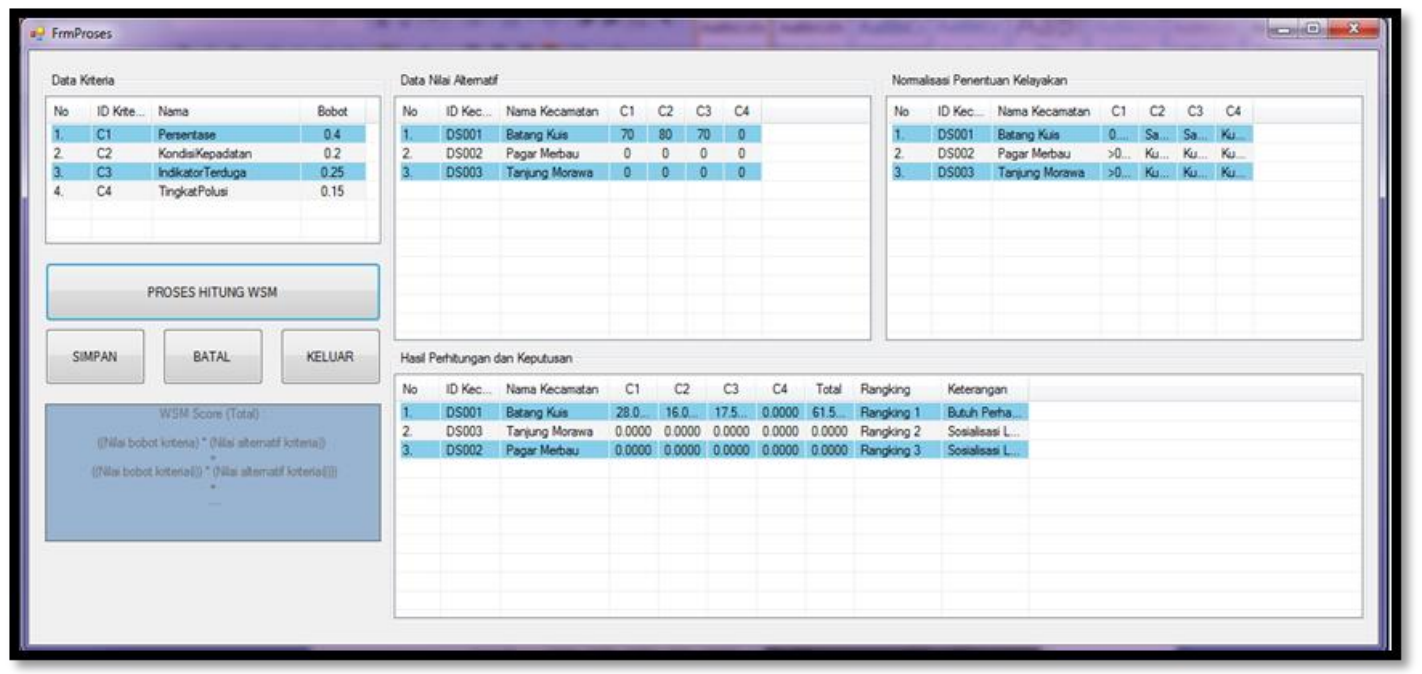




\section{KESIMPULAN}

Dari hasil pengujian dan evaluasi yang telah dilakukan sebelumnya, maka dapat diperoleh kesimpulan untuk kemajuan analisa yang dibuat. Dengan adanya kesimpulan akan didapatkan suatu perbandingan yang akhirnya member perbaikan perbaikan pada masa yang akan datang. Adapun kesimpulan yang diperolah adalah:

1. Berdasarkan hasil analisa permasalahan yang terjadi, maka metode Weighted Sum Model dapat diterapkan dalam aplikasi sistem pendukung keputusan untuk menentukan potensi kecamatan gawat tuberculosis pada wilayah kerja TB-HIV care aisyiyah Deli Serdang untuk memberikan petunjuk kepada pihak lembaga swadaya masyarakat untuk menindak lanjuti penyebaran kasus tuberculosis.

2. Aplikasi pendukung keputusan yang mengadopsi metode Weighted Sum Model dirancang dengan membuat use case diagram, class diagram, membuat database, dan merancang menggunakan visual basic.

3. Dengan menggunakan aplikasi sistem pendukung keputusan yang dirancang dapat membantu lembaga untuk memetakan supek tuberculosis, sehingga dapat menurunkan jumlah kasus tuberculosis di Deli Serdang.

\section{REFERENSI}

[1] Dicky Nofriansyah, S.kom., M.Kom \& Prof. DR. Sarjon Defit, S.kom., M.kom. 2017. Multi Criteria Decision Making (MCDM) Pada Sistem Pendukung Keputusan. Yogyakarta : Penerbit Deepublish (CV Budi Utama).

[2] Mesran, Sugiman, Surya Darma Nasution, \& Andsyah Putera Utama Siahaan. 2017. Penerapan Weighted Sum Model (WSM) Dalam Penentuan Peserta Jaminan Kesehatan Masyarakat. Jurnal Riset Sistem Dan Tehnik Informatika (JURASIK). Volume (2).

[3] Rosa A.S \& M. Shalahuddin. 2016. Rekayasa Perangkat Lunak Terstruktur Dan Berorientasi Objek. Bandung : Informatika.

[4] Sri Eniyati. 2011. Perancangan Sistem Pendukung Keputusan Untuk Penerimaan Beasiswa Dengan Metode SAW (Simple Additive Weighting). Jurnal Teknologi Infomasi DINAMIK Vol 16, 171-176.

[5] Stefano, S.kom. 2014. Cara mudah Membangun Sistem Informasi Menggunakan VB.NET dan komponen DXperience. 